\title{
Physico-mechanical properties of the wood of freijó, Cordia goeldiana (Boraginacea), produced in a multi-stratified agroforestry system in the southwestern Amazon
}

\author{
Adriano Reis Prazeres MASCARENHAS ${ }^{1 *}$,, Marta Silvana Volpato SCCOTI $^{1}$, Rafael Rodolfo de MELO², \\ Fernando Luíz de Oliveira CORREA ${ }^{3}$, Emanuel Fernando Maia de SOUZA ${ }^{1}$, Alexandre Santos PIMENTA ${ }^{4}$ \\ Universidade Federal de Rondônia, Departamento Acadêmico de Engenharia Florestal, Av. Norte Sul 7300, 76940-000, Rolim de Moura, RO, Brazil \\ Universidade Federal Rural do Semi-Árido, Departamento de Ciências Agronômicas e Florestais, Av. Francisco Mota 572, 59625-900, Mossoró, RN, Brazil \\ Comissão Executiva do Plano da Lavoura Cacaueira - CEPLAC, Superintendência de Desenvolvimento da Região Cacaueira do Estado de Rondônia, BR - 364, km \\ 325, 35400-000, Ouro Preto do Oeste, RO, Brasil. \\ 4Universidade Federal do Rio Grande do Norte, Unidade Acadêmica de Ciências Agrárias, RN-160, Km 03, 59280-000, Distrito de Jundiaí, Macaíba, RN, Brazil \\ * Corresponding author: adriano.mascarenhas@unir.br; (D) https://orcid.org/0000-0002-7554-3590
}

\section{ABSTRACT}

Agroforestry systems (AFSs) integrate, through sustainable practices, agricultural and forest crops for the production of wood and food, providing environmental services, and conserving biodiversity. The freijó (Cordia goeldiana) has potential for cultivation in the Amazon for timber purposes, but data on the characteristics of its wood produced in AFSs are scarce. Our objective was to determine the physical-mechanical properties and suggest technological applications of freijó wood produced in a multi-stratified AFS established in the state of Rondônia, Brazil in 1996. Agricultural and forest species were established in the AFS in double rows with 5.0-m x 2.5-m spacing. Three 19-year-old freijó trees were harvested for chemical, physical (density and dimensional stability), and mechanical (compression, static bending, Janka hardness, and shear strength) characterization of the wood. The wood presented a chemical composition similar to tropical hardwoods, was moderately heavy $\left(582.63 \mathrm{~kg} \mathrm{~m}^{-3}\right)$, and had high dimensional stability in comparison with other consecrated woods on the market (longitudinal, radial, and tangential retraction $=0.25,4.27$, and $6.83 \%$, respectively). The values determined for parallel (32.32 MPa) and perpendicular compression $(8.02$ $\mathrm{MPa})$, specific strength $\left(55.32 \mathrm{MPa} \mathrm{kg}^{-1} \mathrm{~m}^{-3}\right)$, parallel $(2373.33 \mathrm{~N})$ and perpendicular Janka hardness $(2326.67 \mathrm{~N})$, strength to static bending $(63.5 \mathrm{MPa})$, and shear $(5.94 \mathrm{MPa})$ were similar to the values observed in other high-density tropical woods grown in either monoculture plantations or natural forests. The wood under study is suitable for manufacture of high-value-added products, such as fine furniture, residential floors, musical instruments and structural pieces.

KEYWORDS: tropical wood, agroecosystems, chemical composition, mechanical properties, physical properties

\section{Propriedades físico-mecânicas da madeira de freijó, Cordia goeldiana (Boraginacea), produzida em sistema agroflorestal multiestratificado no sudoeste da Amazônia}

\section{RESUMO}

Os sistemas agroflorestais (SAFs) integram, com práticas sustentáveis, culturas agrícolas e florestais para produção de madeira e alimentos, conservando os serviços ambientais e a biodiversidade. $\mathrm{O}$ freijó, Cordia goeldiana, tem potencial para cultivo na Amazônia para fins madeireiros, porém dados sobre as características de sua madeira em SAFs são escassas. Objetivou-se determinar as propriedades físico-mecânicas e aplicaçôes tecnológicas da madeira de freijó produzida em um SAF multiestratificado estabelecido no estado de Rondônia, Brasil em 1996. No SAF, as espécies agrícolas e madeireiras foram estabelecidas em renques duplos no espaçamento 5,0 m x 2,5 m. Abateram-se três árvores de freijó com 19 anos de idade, para caracterização química, física (densidade e estabilidade dimensional) e mecânica (compressão, flexão estática, dureza Janka e cisalhamento) da madeira. A madeira de freijó apresentou composição química similar à de madeiras nobres tropicais, peso moderado $\left(582,63 \mathrm{~kg} \mathrm{~m}^{-3}\right)$ e estabilidade dimensional elevada em comparação com outras madeiras consagradas no mercado (retração longitudinal, radial e tangencial = $0,25,4,27$ e 6,83\%, respectivamente). Os valores de resistência à compressão paralela (32,32 MPa) e perpendicular (8.02 MPa), resistência específica $\left(55,32 \mathrm{MPa} \mathrm{kg}^{-1} \mathrm{~m}^{-3}\right)$, dureza Janka paralela $(2373,33 \mathrm{~N})$ e perpendicular $(2326,67 \mathrm{~N})$, resistência à flexão estática $(63,5 \mathrm{MPa})$ e ao cisalhamento $(5,94 \mathrm{MPa})$ foram semelhantes aos valores observados em outras madeiras tropicais de alta densidade, produzidas em monocultivo e florestas naturais. A madeira em estudo é adequada para fabricação de produtos de alto valor agregado, como móveis finos, pisos residenciais, instrumentos musicais e peças estruturais.

PALAVRAS-CHAVE: madeira tropical, agroecossistemas, composição química, propriedades mecânicas, propriedades físicas 


\section{INTRODUCTION}

In the Brazilian Amazon, the correct planning to balance the conservation of natural resources and agricultural activity is the most intensely discussed subject among researchers, farmers, government, and non-government agencies (Pereira et al. 2019; Reydon et al. 2020). Conventional methods of monoculture or pasture planting have been shown to be harmful to the environment in the Amazon, as they are based on slash-and-burn practices and application of chemical fertilizers that cause rapid depletion of soils, exhaustion of water resources and severe impacts on biodiversity (Abman and Carney 2020; Figueiredo et al. 2020).

With the growing demand for food and the expansion of cultivated areas, the search for alternatives to the conventional agricultural systems is required. To reconcile these aspects with the conservation of ecosystems, agriculture strategies that enable less waste emission, recover degraded areas, reduce deforestation and provide environmental services should be considered (Cortner et al. 2020; Stabile et al. 2020).

Agroforestry systems (AFSs) are inserted in the context of sustainable land uses as they allow to integrate agricultural production with practices of traditional communities and promote soil and biodiversity conservation (Kay et al. 2019). AFSs involve the diversification of farm production and income, the integrated production of wood and food crops, nutrient cycling, recovery of biodiversity and carbon sequestration (Fleming et al. 2019; Rizvi et al. 2019; Bayala and Prieto 2020). The inclusion of high-value native wood species can increase the profitability of AFSs, as species that are well adapted to local edaphoclimatic conditions and ecological interactions, when correctly planted and harvested, can contribute to the decrease of the exploitation of natural forests (Kay et al. 2019; Reis et al. 2020).

Cordia goeldiana Huber (Boraginaceae), regionally known as freijó in the Brazilian Amazon, is a neotropical tree species native to Central and South America (Matias et al. 2015). It is considered a high-value-added tree species and its wood is commercialized with prices varying from 126 to $140 \mathrm{US} \$ \mathrm{~m}^{-3}$ (Soares-Filho et al. 2017). This wood species has the potential to be employed in the establishment of commercial plantations in the Amazon region, due to its high productivity of biomass, tolerance to variations in soil fertility, interaction with the local fauna, and natural resistance to pest attacks and diseases (Gomes et al. 2010).

Furthermore, freijó is easy to manage for commercial wood production (Santos et al. 2017). Its wood has natural durability, good acceptance in local and international markets, has suitable properties for use in the manufacture of engineered panels and musical instruments, and is a potential source of cellulose nanofibers and bioactive compounds (Lima et al. 2013; Matias et al. 2015; Moulin et al. 2016; Scatolino et al. 2017; Barros and Politano 2019).
Management practices and spatial arrangement have a strong influence on both height and diameter growth of trees (Bello et al. 2019; Pachas et al. 2019). In natural forests, site quality, mechanical stress on the trunk, spacing, water availability and species diversity promote significant alterations in chemical composition, anatomical patterns and physico-mechanical properties of wood (Rizant et al. 2018; Pamerlau-Couture et al. 2019; Zalloni et al. 2019).

Studies on wood characteristics of freijó grown in monospecific plantations and AFSs are scarce (Aires 2008; Cordeiro et al. 2015). The assessment of the quality of wood from AFSs is particularly relevant, since the dynamics and growth conditions in these systems depend on the diversity of component species and the temporal and spatial variation in plant density (Dawoe et al. 2018; Huber et al. 2020).

In the present study, we assessed the physico-mechanical properties of wood from freijó trees grown in a multi-stratified AFS located in an Amazonian rainforest area.

\section{MATERIAL AND METHODS}

\section{Study area}

The study was carried out in the experimental station of CEPLAC (Comissão Executiva do Plano da Lavoura Cacaueira) (1043'6.36”S, 62¹3'22.17'W; 249 m above sea level), located in the municipality of Ouro Preto do Oeste, in Rondônia state, northern Brazil (Figure 1).

The predominant soil is red-yellow eutrophic argisol (Santos et al. 2018), The native forest typologies in the region are submontane dense ombrophilous forest with uniform canopy, submontane dense ombrophilous forest with emergent canopy, and submontane open ombrophilous forest with palm trees (Mascarenhas et al. 2017). The climate is Am by the Köppen-Geiger classification, with annual average temperature and rainfall of $26^{\circ} \mathrm{C}$ and $2,300 \mathrm{~mm}$, respectively, and relative humidity varying from 80 to $90 \%$ (Alvares et al. 2013).

\section{AFS characteristics}

The AFS's total area is 1 ha and it was established in 1996 by using seedlings. The components were planted in double ranks with spacing of $5.0 \mathrm{~m} \times 2.5 \mathrm{~m}$, totaling 800 freijó trees per ha. Fertilization of the AFS was carried out by applying $2.0 \mathrm{t} \mathrm{ha}^{-1}$ of limestone in the whole area and $150 \mathrm{~g}$ of N-P-K (4-14-8) for each freijó tree. The floristic composition, spacing, size and planting density of the ASF are summarized in Table 1, and the spatial distribution and arrangement of the ASF are schematically presented in Figure 2. During the existence of the AFS, silvicultural practices such as weed control and pruning have been employed. The physical-chemical characteristics of the soil (Table 2) of the experimental plot were determined by following the methodology by Mascarenhas et al. (2017). 


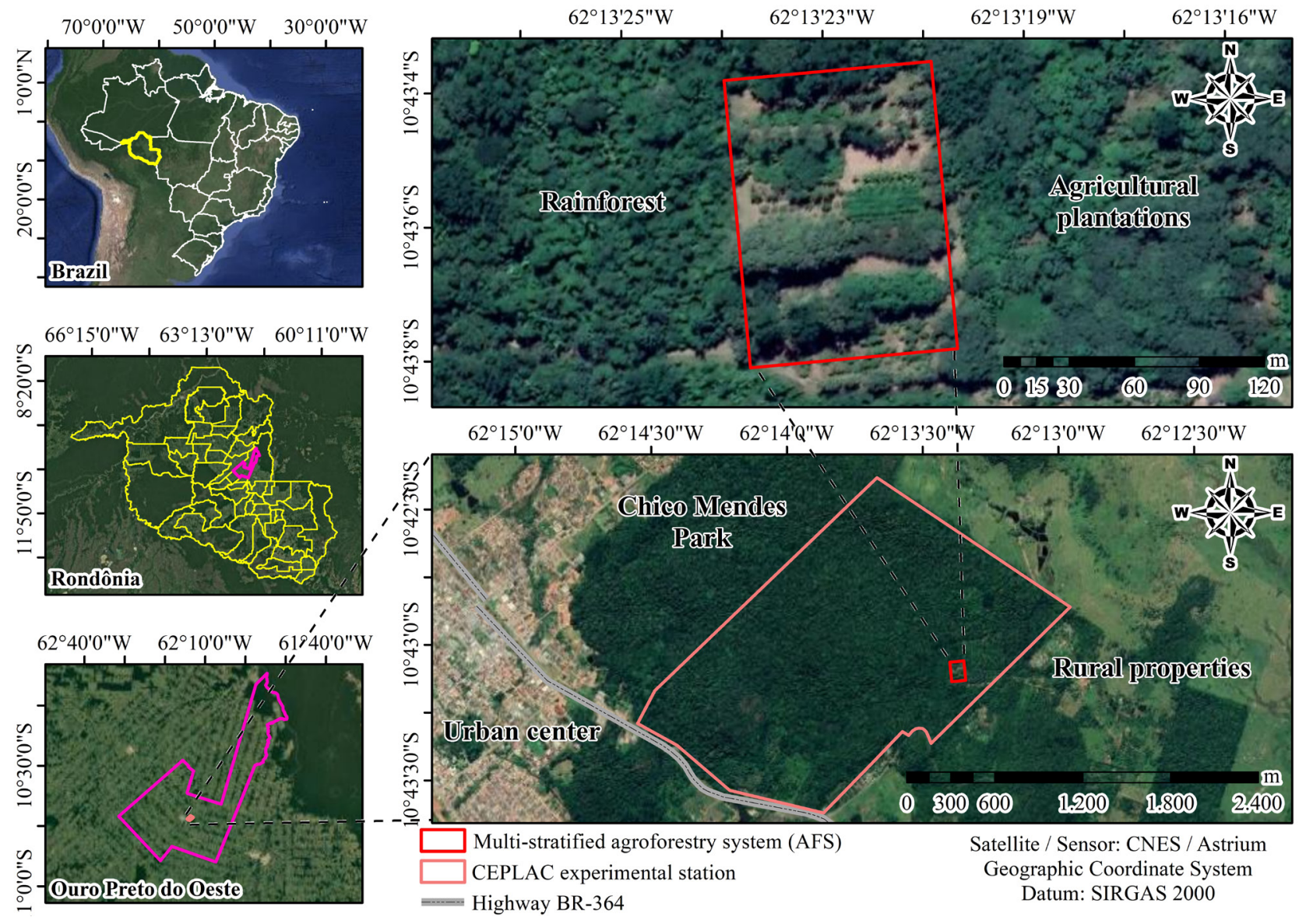

Figure 1. Location of the agroforestry system in the CEPLAC experimental station, in the municipality of Ouro Preto do Oeste, Rondônia state, Brazil. This figure is in color in the electronic version.

Table 1. Floristic composition, spacing, height and planting density in the agroforestry system under study, located in Ouro Preto do Oeste, Rondônia, Brazil.

\begin{tabular}{lccc}
\hline Species & $\begin{array}{c}\text { Spacing } \\
(\mathrm{m} \times \mathrm{m})\end{array}$ & Height & $\begin{array}{c}\text { Density } \\
\left(\text { plants ha- }{ }^{-1}\right)\end{array}$ \\
\hline Cordia goeldiana & $5.0 \times 2.5$ & Large & 800 \\
\hline Eugenia stipitata & $5.0 \times 2.5$ & Small & 800 \\
Theobroma cacao & $(2.0 \times 1.5) \times 4.0$ & Small & 625 \\
Theobroma grandiflorum & $4 \times 5$ & Small & 444 \\
Spondia mombim & $5.0 \times 2.5$ & Medium & 800 \\
Cocos nucifera & $5.0 \times 2.5$ & Large & 800 \\
Arthocarpus altilis & $5.0 \times 2.5$ & Large & 800 \\
Citrus sinensis & $5.0 \times 2.5$ & Small & 800 \\
Mangifera indica & $5.0 \times 2.5$ & Large & 800 \\
Bactris gasipaes & $5.0 \times 2.5$ & Large & 800 \\
\hline
\end{tabular}

Table 2. Physical-chemical characteristics of the soil in the agroforestry system under study, located in Ouro Preto do Oeste, Rondônia, Brazil.

\begin{tabular}{lcccccccccccc}
\hline Depth & $\mathrm{pH}$ & $\mathrm{pH}$ & $\mathrm{V}$ & $\mathrm{P}$ & $\mathrm{K}$ & $\mathrm{Ca}$ & $\mathrm{Mg}$ & $\mathrm{Al}$ & Sand & Silt & Clay \\
\cline { 5 - 12 }$(\mathrm{cm})$ & $\left(\mathrm{H}_{2} \mathrm{O}\right)$ & $\left(\mathrm{CaCl}_{2}\right)$ & $\%$ & \multicolumn{2}{c}{$\mathrm{mg} \mathrm{dm}^{-3}$} & \multicolumn{4}{c}{$\mathrm{Cmol}_{\mathrm{c}} \mathrm{dm}^{-3}$} & & $\mathrm{~g} \mathrm{~kg}^{-1}$ & \\
\hline $0-20$ & 5.80 & 5.20 & 59.10 & 2.50 & 41.00 & 2.00 & 0.42 & 0.00 & 661.00 & 128.00 & 211.00 \\
$20-40$ & 5.90 & 5.10 & 63.20 & 1.20 & 50.00 & 1.26 & 0.33 & 0.00 & 600.00 & 143.00 & 257.00 \\
\hline
\end{tabular}




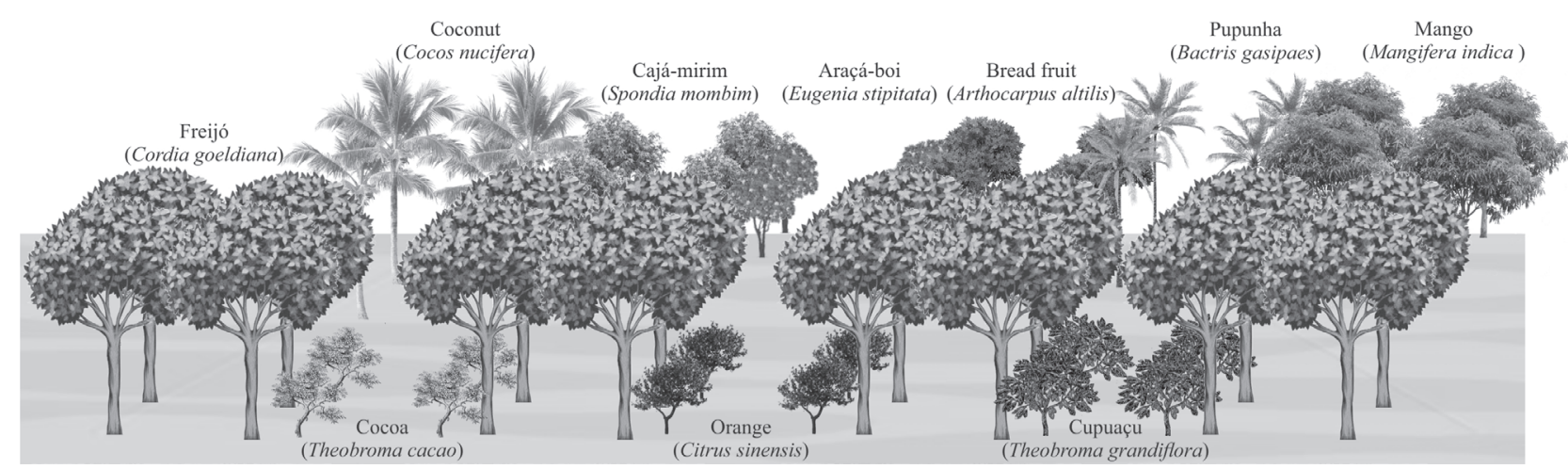

Figure 2. Scheme of distribution and spatial arrangement of species cultivated in the agroforestry system under study, located in Ouro Preto do Oeste, Rondônia, Brazil.

\section{Dendrometric characteristics and wood sampling}

The following dendrometric variables were obtained from 32 trees measured in the AFS: number of trees per hectare $(\mathrm{N})$, diameter at breast height $(\mathrm{DBH})$, total height $(\mathrm{TH})$, commercial height $(\mathrm{CH})$, basal area $(\mathrm{G})$, volume per hectare $(\mathrm{V})$ and form factor (FF). Complementary information regarding methods of data collection and economic aspects of the species can be found in Virgulino et al. (2015). With the collected data, the basal area diameter $(18.25 \mathrm{~cm})$ was calculated and used as selection criterium for better representation in the selection of trees for wood analysis. According to the requirements of ASTM D 5536 (ASTM 2017), three freijó trees with good phytosanitary conditions, free of bifurcations, tortuosity and irregular grain were harvested.

From each felled tree, logs were removed from the DBH region measuring $1.5 \mathrm{~m}$ in length. The logs were converted into blocks of only heartwood with dimensions of $0.12 \mathrm{~m}$ $\times 0.12 \mathrm{~m} \times 1.50 \mathrm{~m}$ (width $\times$ thickness $\times$ length). Then, twelve specimens were made for each chemical, physical and mechanical test. Care was taken that the samples produced were perfectly oriented in the radial and tangential directions in relation to the longitudinal axis of the trees and free of defects such as knots and irregular grain.
The steps followed to obtain the test specimens were: (a) samples for the determination of chemical composition, basic and apparent densities, porosity, linear and volumetric shrinkage and anisotropy factor (coefficient of anisotropy); (b) samples for the parallel-to-grain compression assay; (c) samples for the perpendicular-to-grain compression and perpendicular and parallel-to-grain Janka hardness assays; (d) samples for the shear strength assay; and (e) samples for the static bending assay (Figure 3).

\section{Chemical composition}

For the chemical composition determination, test specimens were ground in a wood shredder and converted into sawdust using a Wiley mill. According to the procedures described in ABNT NBR 14660 (ABNT 2003a), the final sawdust was divided into three fractions with the following granulometries: below 40 mesh, 40 to 60 mesh and above 60 mesh. The 40-to-60-mesh fraction was used to measure extractives, lignin and ash contents, following the procedures of ABNT NBR 14853, NBR 7989 and NBR 13999 (ABNT 2003b, c and d), respectively. Holocellulose content was calculated as the difference between the initial dry mass of wood and the sum of extractives, lignin and ash.

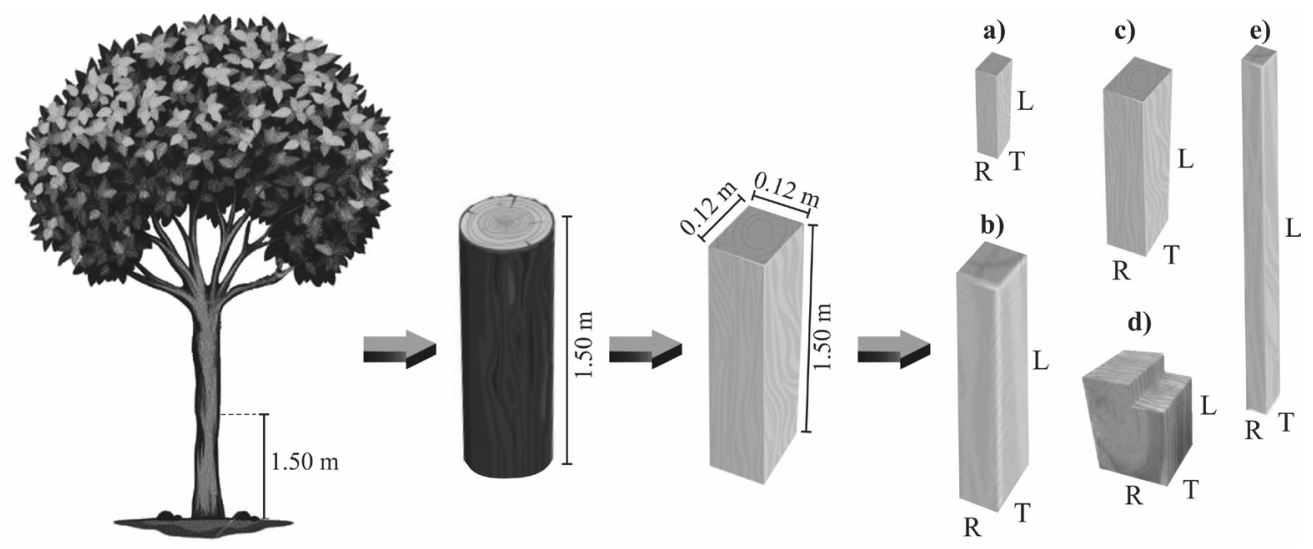

Figure 3. Scheme employed for freijó (Cordia goeldiana) wood sampling and collection of test specimens for chemical and physical-mechanical assessments. 


\section{Physical properties}

Test specimens measuring $25 \mathrm{~cm} \times 25 \mathrm{~cm} \times 100 \mathrm{~mm}$ were cut according to the procedures from the standard ASTM D 143 (ASTM 2014). These test specimens were immersed in water until complete saturation and stabilization of linear dimensions (width, thickness and length). By the stereometric method, dimensions and mass were measured with a digital pachymeter and a semi-analytical scale, respectively, according to NBR 11941 (ABNT 2003e). The test specimens were kept in a conditioning room at $20{ }^{\circ} \mathrm{C}$ and relative humidity of $65 \%$ until reaching hygroscopic equilibrium.

The apparent density $\left(\rho_{a}\right)$ was calculated as the ratio between the weight and volume of the test specimens after they reached equilibrium. For basic density $\left(\rho_{b}\right)$ calculation, the test specimens were oven dried at $105^{\circ} \mathrm{C}$ until constant weight and the final weight was divided by their saturated volumes. The porosity of the wood was calculated using the equation:

$$
\Phi=\left(1-\rho_{a} / \rho_{p}\right) \times 100 .
$$

where $\Phi$ is the porosity of the wood (\%); $\rho_{a}$ is the basic density of the wood $\left(\mathrm{kg} \mathrm{m}^{-3}\right)$; and $\rho_{p}$ is the density of the cell wall $\left(\cong 1540 \mathrm{~kg} \mathrm{~m}^{-3}\right)$.

Values of radial $\left(\beta_{r}\right)$, tangential $\left(\beta_{t}\right)$, longitudinal $\left(\beta_{l}\right)$ and volumetric $\left(\beta_{v}\right)$ shrinkage were determined by the ratio between the difference of dimensions of saturated and dry samples and the corresponding dimensions after saturation. The anisotropy factor $\left(A_{f}\right)$ was determined as the ratio between tangential and radial shrinkage. The standard used to determine the dimensional stability variables was NBR 7190 (ABNT 1997).

\section{Mechanical properties}

Assay speed and the dimensions of the test specimens employed in the assessment of the mechanical properties of the wood followed the standard ASTM D 143 (ASTM 2014). The test specimens were conditioned at the same temperature and relative humidity mentioned in the previous topic. Then they were assayed in a universal testing machine equipped with a load cell of $30 \mathrm{kN}$ to measure the strength and modulus of elasticity to parallel $\left(f_{c 0}\right.$ and $\left.E_{c 0}\right)$ and perpendicular $\left(f_{c 90}\right.$ and $\left.E_{c 90}\right)$ compression; specific strength $\left(f_{c d} / \rho_{a}\right)$; strength and modulus of elasticity to static bending $\left(f_{M}\right.$ and $\left.E_{M}\right)$; tangentialgrain shear strength $\left(f_{v 0}\right)$ and parallel and perpendicular shear strength $\left(f_{H O}\right.$ and $\left.f_{H 9 O}\right)$. Classification and quantification of the rupture failures in the test specimens from parallel-to-grain compression and static bending assays were achieved.

\section{RESULTS}

\section{Dendrometric characterization}

There was low variation in the dendrometric parameters among the trees. The stand density decreased $15.6 \%$ from 800 trees $\mathrm{ha}^{-1}$ at the establishment of the AFS to 625 trees $^{-1} \mathrm{a}^{-1}$ at harvesting. Mean annual increment (MAI) in height was 0.67 $\mathrm{m}$ tree $^{-1}$ and the average commercial height corresponded to $63.5 \%$ of the tree total height (Table 3 ).

The MAI of the diameter at breast height $(\mathrm{DBH})$, basal area and volume were $0.91 \mathrm{~cm}_{\text {tree }}^{-1}$ year $^{-1}, 0.93 \mathrm{~m}^{2} \mathrm{ha}^{-1}$ year ${ }^{-1}$ and $6.47 \mathrm{~m}^{3} \mathrm{ha}^{-1}$ year $^{-1}$, respectively. Based on the form factor, the trunks presented accentuated taper.

\section{Chemical composition}

The average level of holocellulose was $64.5 \%$ and that of lignin $29.6 \%$. There was low variation among the trees (coefficient of variation, $\mathrm{CV}=0.2 \%$ and $3.1 \%$, respectively). Average values for extractives and ash were $3.6 \%$ and $1.9 \%$, respectively, with corresponding CVs of $23.9 \%$ and $4.2 \%$.

\section{Physical properties}

As with the chemical composition, there was a low variation among trees in the apparent density $(\mathrm{CV}=7.1 \%)$, basic density $(\mathrm{CV}=3.9 \%)$ and wood porosity $(\mathrm{CV}=1.6 \%)$ (Table 4$)$.

Table 3. Stand density and dendrometric parameters observed for 19-year-old freijó (Cordia goeldiana) trees in an agroforestry system located in Ouro Preto do Oeste, Rondônia, Brazil. Values are the mean \pm standard deviation of 32 trees.

\begin{tabular}{lcc}
\hline Parameter & Measure unit & Values \\
\hline Stand density & trees ha ${ }^{-1}$ & 675 \\
Total height & $\mathrm{m}$ & $12.77 \pm 4.28$ \\
Commercial height & $\mathrm{m}$ & $8.11 \pm 2.72$ \\
Diameter at breast height & $\mathrm{cm}$ & $17.22 \pm 6.14$ \\
Basal area & $\mathrm{m}^{2} \mathrm{ha}^{-1}$ & 17.65 \\
Volume per hectare & $\mathrm{m}^{3} \mathrm{ha}^{-1}$ & 122.98 \\
Form factor & - & $0.49 \pm 0.18$ \\
\hline
\end{tabular}

Table 4. Experimental range of physical properties of wood of freijó (Cordia goeldiana) grown in an agroforestry system in Rondônia, Brazil. $\rho_{a}=$ apparent density; $\rho_{b}=$ basic density; $\Phi=$ porosity; $\beta_{r}=$ radial shrinkage; $\beta_{t}=$ tangential shrinkage; $\beta_{l}=$ longitudinal shrinkage; $\beta_{v}=$ volumetric shrinkage; $A f=$ anisotropic coefficient. Values are the mean \pm standard deviation of 12 samples from three trees.

\begin{tabular}{lcc}
\hline Parameter & Measure unit & Values \\
\hline$\rho_{a}$ & $\mathrm{~kg} \mathrm{~m}^{-3}$ & $582.63 \pm 41.39$ \\
$\rho_{b}$ & $\mathrm{~kg} \mathrm{~m}^{-3}$ & $444.30 \pm 17.30$ \\
$\Phi$ & $\%$ & $71.15 \pm 1.12$ \\
$\beta_{i}$ & $\%$ & $0.25 \pm 0.16$ \\
$\beta_{r}$ & $\%$ & $4.27 \pm 1.00$ \\
$\beta_{t}$ & $\%$ & $6.83 \pm 1.66$ \\
$\beta_{v}$ & $\%$ & $11.01 \pm 2.36$ \\
Af & - & $1.64 \pm 0.38$ \\
\hline
\end{tabular}


The dimensional stability parameters also presented low variability (Table 4). Based on the anisotropy factor, an increasing trend was observed for the linear shrinkage, so that $\beta_{l}<\beta_{r}<\beta_{t}$, and $\beta_{t}$ was $38 \%$ higher than $\beta_{r}$, as expected for $\beta$, since it is the product of linear shrinkages. Higher values of $\beta_{t}$ were determined, but with lower variation than in the other evaluated parameters.

\section{Mechanical properties}

Average $f_{c 0}$ was about $75 \%$ higher than average $f_{c 00}$. Average $f_{c 0} / \rho_{a}$ was $55.47 \mathrm{MPa} \mathrm{kg}^{-1} \mathrm{~m}^{-3}$ and a high modulus of elasticity was observed for compression regardless of the assay (Table 5).

The types of failures observed in the parallel-to-grain compression assay were crushing (60\%), wedge splitting $(20 \%)$, splitting $(10 \%)$ and parallel-to-grain compression and shearing (10\%). The highest values of strength among all the tests were determined for $f_{M}$, and the lowest for $f_{v 0}$. The main ruptures observed in the static bending assay were simple tension and cross-grain tension types, with frequencies of 9.1 and $90.9 \%$, respectively. Finally, $f_{H O}$ was only $1.2 \%$ higher than $f_{H 90}$ strength.

\section{DISCUSSION}

\section{Dendrometric characterization}

The small decrease in the density of freijó trees along time very likely can be attributed to the adaptation of the forest stand to the environment of the experimental plot, so that density trended towards the common pattern in the Amazon region for this species, which is a heliophile and moderately demanding of fertile soils (Matias et al. 2015). A similar pattern of distribution per hectare was observed for the growth of freijó in secondary forests (Cordeiro et al. 2019).

Table 5. Experimental range of mechanical properties of wood of freijó (Cordia goeldiana) grown in an agroforestry system in Rondônia, Brazil. $f_{c 0}=$ parallel-tograin strength to compression; $E_{c 0}=$ parallel-to-the grain stiffness to compression; ${ }_{c} / \rho_{a}=$ specific resistance; $f_{c 90}=$ perpendicular-to-grain strength to compression; $E_{c 90}=$ perpendicular-to-grain stiffness to compression; $f_{H O}=$ parallel-to-grain Janka hardness; $f_{H 90}=$ perpendicular-to-grain Janka hardness; $f_{M}=$ strength to static bending; $E_{M}=$ stiffness to static bending; $f_{w 0}=$ strength of tangential-to-grain shear test. Values are the mean \pm standard deviation of 12 samples from three trees.

\begin{tabular}{lcc}
\hline Parameter & Measure unit & Values \\
\hline$f_{c 0}$ & $\mathrm{MPa}$ & $32.32 \pm 1.45$ \\
$E_{c 0}$ & $\mathrm{MPa}$ & $10742.77 \pm 588.76$ \\
$f_{c 0} / \rho_{a}$ & $\mathrm{MPa} \mathrm{kg}{ }^{-1} \mathrm{~m}^{-3}$ & $55.32 \pm 5.30$ \\
$f_{c 00}$ & $\mathrm{MPa}$ & $8.02 \pm 1.03$ \\
$E_{c 90}$ & $\mathrm{MPa}$ & $2111.60 \pm 502.53$ \\
$f_{H 0}$ & $\mathrm{~N}$ & $2373.33 \pm 430.70$ \\
$f_{\text {H90 }}$ & $\mathrm{N}$ & $2326.67 \pm 396.61$ \\
$f_{M}$ & $\mathrm{MPa}$ & $63.50 \pm 12.33$ \\
$E_{M}$ & $\mathrm{MPa}$ & $6905.40 \pm 1166.77$ \\
$f_{v 0}$ & $\mathrm{MPa}$ & $5.94 \pm 1.24$ \\
\hline
\end{tabular}

No thinning was conducted and no diseases were observed in our ASF during its maturation, thus the main cause of the decrease in freijó density is likely owed to the suppression of seedlings or plants with lower rusticity due to events that commonly occur in the region, such as ant attacks during the establishment of forest stands, water stress during the 4-5-month dry season or breakage caused by strong winds during torrential rains, as described by Alvares et al. (2013).

Similar growth parameters to ours were observed in the southern Amazon for the development of freijó at five years of age, although the MAI was higher (1.22 $\mathrm{m} \mathrm{tree}^{1}$ year $\left.^{1}\right)$ (Rezende and Vieira 2019). In the latter study, the trees were planted at denser spacing than in our study, which knowingly causes plants to prioritize growth in height rather than diameter due to the competition for sunlight (Chery et al. 2020; Kuehne et al. 2020). In our AFS, the growing space of $12.50 \mathrm{~m}^{2}$ was higher than that usually employed in monospecific plantations of freijó, which favored diameter growth in the early years. The accentuated taper observed in the trunks supports this assessment. However, DBH from 30 to $60 \mathrm{~cm}$ were reported for freijó in natural forests (Lima et al. 2013; Moulin et al. 2016; Scatolino et al. 2017), which indicates that the trees in our experiment had not yet attained their maximum growth, needing more time to reach rotation age.

\section{Chemical composition}

The chemical composition of the freijó wood was in accordance with tropical hardwoods (Gérard et al. 2019; Qiu et al. 2019). Similar content levels were observed in 25-30-year old freijó wood from natural forests, except for higher levels of holocellulose (78\%) and extractives (7\%) (Scatolino et al. 2017). Environmental factors such as climate, soil and water availability, along with management practices and age, strongly influence the chemical composition of wood. For example, the ash content of Cedrela odorata L. grown in an AFS decreased with age (Tenorio and Moya 2019). In Tectona grandis Linn f., holocellulose, lignin and extractives content varied among different management systems in which the trees were grown (Rizanti et al. 2018). The impregnation of wood cells with extractives can vary in water storage tissues (Jankowska et al. 2017), influencing the permeability and physical-mechanical properties of the wood (Bak et al. 2019).

Pharmacological prospection of the extractives of freijó wood detected molecules with antimicrobial, antiinflammatory, and anti-parasitic properties (Matias et al. 2015). The freijó wood is also suited for the production of cellulosic nanofibers (Scatolino et al. 2017), which is also indicated by the holocellulose content in our samples.

\section{Physical properties}

According to the basic density and porosity values, freijó wood can be classified as moderately heavy (Pereira 2013). The low 
variability among the trunks indicates that the wood tends to be homogenous, despite interindividual genetic variation. Our 19-year old trees were classified as juveniles at harvest, and contained an unbalanced proportion of earlywood and latewood, which, nonetheless, was not reflected in higher variability of density, even though the samples were collected randomly in the pith-to-bark direction.

Juvenile wood is characterized by presenting 10 to 20 growth rings, reduction in microfibrillar angle, increase in the amount of latewood, and greater cell thickness and density in the pith-to-bark direction (Moore and Crown 2017). Some reference values for freijó wood quality can be obtained from Alves et al. (2013) and Lima et al. (2013), who found $\rho_{a}$ and $\rho_{b}$, for wood from natural forests of about 590 and $504 \mathrm{~kg} \mathrm{~m}^{-3}$, respectively. The characteristics of our freijó samples were similar to those of other species cultivated worldwide, such as teak (Tectona grandis), with values of $\rho_{a}$ and $\rho_{b}$ around 580 and $430 \mathrm{~kg} \mathrm{~m}^{-3}$, respectively (Rizanti et al. 2018; Amoah and Inyong, 2019; Kenzo et al. 2020).

This comparison allows to identify the possible range of wood products that can be obtained from freijó, since wood from different species can be grouped according to similar technological properties. This knowledge based on comparison with other species can encourage farmers to include native trees adapted to the local edaphoclimatic conditions in planted forests and help reduce overexploitation of natural forests (Reis et al. 2019).

Following Sargent (2019), the shrinkage and anisotropy values of our freijo samples indicate that the wood has high dimensional stability, with low tendency to crack and warp. The wood is thus adequate for manufacture of high-value products, such as fine furniture, miters and other wood articles that require precise measures and only tolerate slight dimensional variations. Due to its physical properties, freijó wood is also suitable for the production of musical instruments (e.g., backs of guitars) (Barros and Politano 2019).

The dimensional stability of our freijó-wood samples was higher than that reported for other valuable tropical timber species with solid position in the local and international wood market, such as Tabebuia serratifolia Vabl Nich. (ipê), with values of $5.1 \%$ and $7.8 \%$ for $\beta_{r}$ and $\beta$, respectively (Dias et al. 2019). Parameters of dimensional stability are important to guide the correct application and sizing of solid wood pieces, as they guide the processing steps to which wood can be submitted, such as thermal treatment, use of coatings and fillers and drying processes (Ramage et al. 2017).

\section{Mechanical properties}

Besides high dimensional stability, our freijó wood also presented high mechanical stability due to the low variability in the evaluated parameters, especially wood density, which is highly correlated with the mechanical properties, and its variability directly affects the modulus of rupture and elasticity (Hein and Brancheriau 2018). Based on the results observed for $f_{c 0}$ and $E_{c 0}$, the wood has intermediate mechanical strength and high modulus of elasticity. Its $f_{c o} / \rho_{a}$ ratio, or specific strength, of $55.3 \mathrm{MPa} \mathrm{kg}^{-1} \mathrm{~m}^{-3}$, is close to that of other highdensity tropical woods, such as Manilkara amazonica (Huber) A. Chev. (maçaranduba) and Mezilaurus itauba (Meisn.) Taub. ex Mez (itaúba), with specific strengths of 57.2 and $63.0 \mathrm{MPa}$ $\mathrm{kg}^{-1} \mathrm{~m}^{-3}$, respectively (Dias et al. 2019). This characteristic allows freijó wood to be used to build lighter structures with similar strength to that of $M$. amazonica and $M$. itauba without making significant changes in the size of the pieces.

The ruptures of the test specimens in the compression assay were considered normal, indicating that the wood is uniform and highly resistant. The analysis of ruptures revealed that the failures were not influenced by the possible presence of alterations or defects in the anatomical constitution of the wood. Usually non-uniformity in wood is associated with the presence of knots, tension in the wood, and irregular grain, which negatively affect the physical-mechanical properties and can result from genetic traits, silvicultural practices and management systems (Groover 2016).

Values of $f_{c 00}$, lower than $f_{c 0}$ are considered normal, because the load applied is distributed tangentially to the cell wall, where the moment of inertia is lower than that in the transversal direction (Helińska-Raczkowska and Moliński 2003). Therefore, due to the voids in fiber lumens, there is a trend for flattening in the compressed region of the test specimen (Navi and Heger 2011; Mania et al. 2020). The perpendicular-to-grain assay, aims to evaluate the material for specific end uses such as decks, railway sleepers, and parquet flooring (Alinoori et al. 2020). With this test, it is possible to predict the risk of the wood undergoing crushing of fibers during elastic deformation under static stress (Kloiber et al. 2015). The Janka hardness results indicated that the freijo wood had medium resistance to penetration. Other published values for this property in freijó wood are 5962 and $4433 \mathrm{~N}$ for $f_{H O}$ and $f_{H 90}$, respectively (Araújo 2007), which are higher than those in our sample. It is important to highlight that Araújo (2007) assessed wood from mature trees in natural forests with higher proportions of latewood in the trunks. Higher proportions of mature wood increase its density and, consequently, its hardness (Evans et al. 2000; Kerkhoff et al. 2015). Janka hardness assays evaluate the resistance to penetration when the static stress is concentrated on a small area (Budakçı et al. 2016), as happens when heavy objects are placed on the material, or when nails, screws, saws and cutters are applied to it.

Similar values of Janka hardness as those observed here for freijó wood, were determined for teak wood, which was classified as moderately resistant to stresses of rolling loads and abrasion, making it suitable for manufacturing residential 
flooring (Blanco-Flórez et al. 2015). Therefore, freijó wood in our ASF could also be indicated for this type of end use.

Our results for $f_{M}$ and $E_{M}$ indicate that, for the rupture of the wood, a load of $647.5 \mathrm{kgf} \mathrm{cm}^{-2}$ would be required. The frequency and type of failures in the test specimens assessed through the static bending assay can be considered normal, so freijo wood satisfies the minimum requirements of, for example, safe load bearing for roof beams and slats. Similarly, Del Menezzi et al. (2010) found values of $f_{M}$ from 70 to 100 $\mathrm{MPa}$ and $E_{M}$ from 8.50 to $12.0 \mathrm{MPa}$ for freijó from natural forests, using non-destructive assays, and Gérard et al. (2017) found $f_{M}$ and $E_{M}$ of 86.0 and 17.27 MPa, respectively, for freijó wood also from natural forests.

Considering $f_{v o}$, the load at rupture in our specimens would be $60 \mathrm{kgf} \mathrm{cm}^{-2}$, but in civil construction, the shear stress tends to occur mainly on joints in pieces that are already supported by others, thus reducing the risk of rupture (Yoshihara and Ohta 2000; Yoshihara and Furushima 2003). In a study to cluster Amazon timber species based on the values of $f_{H 0^{\circ}} f_{H 90^{\prime}}$, $f_{M}$ and $f_{v 0^{\prime}}$, Reis et al. (2019) found that freijo wood (density of $583 \mathrm{~kg} \mathrm{~m}^{-3}$ ) can be included in the same group as wellknown high-resistance woods such as Vochysia maxima Ducke (quaruba) $\left(600 \mathrm{~kg} \mathrm{~m}^{-3}\right)$, Erisma uncinatum Warm. (cambará) $\left(570 \mathrm{~kg} \mathrm{~m}^{-3}\right)$ and Couratari oblongifolia Ducke et R. Knuth (tanari) $\left(610 \mathrm{~kg} \mathrm{~m}^{-3}\right)$. Therefore, our results indicate that freijo wood from trees grown in AFS is compliant with the minimum normative requirements for structure, and can be used for manufacture of beams, rafters, slats and boards.

\section{CONCLUSIONS}

The wood of freijó, Cordia goeldiana from trees grown in an agroforestry system (AFS) was similar to the wood obtained conventionally from either monospecific plantations or native forests. The material presented characteristics compatible with good workability, making it suitable for end uses that demand high dimensional stability. Experimental results for mechanical parameters showed that the wood was within the acceptable limits for structural uses. Extractives content and density had acceptable levels. The use of AFSs enables farmers to diversify their sources of income and the number of products that can be produced from the same land. The parameters assessed in the present work are valuable to support decisions on the end-use of freijó wood from this type of management. The inclusion of freijo trees in AFSs established in the Amazon region is very appealing, since the species is perfectly adapted to the local edaphoclimatic conditions.

\section{ACKNOWLEDGMENTS}

We are especially grateful to CEPLAC (Comissão Executiva do Plano da Lavoura Cacaueira) for financial support and for providing the study material and infrastructure. We would like to thank Universidade Federal de Rondônia and Universidade
Federal de Mato Grosso for providing infrastructure and technical personnel.

\section{REFERENCES}

Abman, R.; Carney, C. 2020. Land rights, agricultural productivity, and deforestation. Food Policy, 94: 101841. doi: 10.1016/j. foodpol.2020.101841

ABNT. 1997. NBR 7190: Design of wooden structures. ABNT, Rio de Janeiro, 107p.

ABNT. 2003a. NBR 14660: Sampling and preparation for analysis. ABNT, Rio de Janeiro, 4p.

ABNT. 2003b. NBR 14853: Determination of material soluble in ethanol-toluene and in dichloromethane. ABNT, Rio de Janeiro, 3p.

ABNT. 2003c. NBR 7989: Cellulosic pulp and wood - Determination of acid insoluble

lignin. ABNT, Rio de Janeiro, 6p.

ABNT. 2003d. NBR 13999: Paper, cardboard, cellulose pulp and wood - Determination of the residue (gray) after incineration at $525^{\circ} \mathrm{C}$. ABNT, Rio de Janeiro, 5p.

ABNT. 2003e. NBR 11941: NBR 11941 Wood-determination of basic density. ABNT, Rio de Janeiro, 6p.

Aires, K. 2008. Cost-benefit analysis of two models of agroforestry systems in Rondônia, Brazil. In: Jepson, W.; Millington, A. (Ed.). Land-Change Science in the Tropics: Changing Agricultural Landscapes, Springer-Nature, New York, p.215-230.

Alinoori, F.; Moshiri, F.; Sharafi, P.; Samali, B. 2020. Reinforcement methods for compression perpendicular-to-grain in top/bottom plates of light timber frames. Construction and Building Materials, 231: 116377.

Alvares, C.A.; Stape, J.L.; Sentelhas, P.C.; Moraes Gonçalves, J.L.; Spavorek, G. 2013. Köppen's climate classification map for Brazil. Meteorologische Zeitschrift, 22: 711-728.

Alves, R.J.; Magalhaes, M.D.C.; Carrasco, E.V.M. 2013. Determination of the transverse Young's modulus (TYM) of wood by means of an input power technique. Construction and Building Materials, 42: 11-21.

Amoah, M.; Inyong, S. 2019. Comparison of some physical, mechanical and anatomical properties of smallholder plantation teak (Tectona grandis Linn.f.) from dry and wet localities of Ghana. Journal of the Indian Academy of Wood Science, 16: 125-138.

Araújo, H.J.B. 2007. Functional relationships among physical and mechanical properties of Brazilian tropical woods. Floresta, 37: 399-416.

ASTM, 2014. ASTM D 143-14: Standard test methods for small clear specimens of timber. (https://www.astm.org/Standards/ D143.htm). Accessed on 18 Oct 2020.

ASTM, 2017. ASTM D 5536-17: Standard practice for sampling forest trees for determination of clear wood properties. (https:// www.astm.org/Standards/D5536.htm). Accessed on 19 Oct 2020.

Bak, M.; Molnár, F.; Németh, R. 2019. Improvement of dimensional stability of wood by silica nanoparticles. Wood Material Science \& Engineering, 14: 48-58. 
Barros, J.O.A.; Politano, R. 2019. Effects of frequency, temperature and test duration in the viscoelasticity of brazilian hardwoods used in handmade musical instruments. Materials Research, 22: e20190190.

Bayala, J.; Prieto, I. 2020. Water acquisition, sharing and redistribution by roots: applications to agroforestry systems. Plant Soil, 453: 17-28.

Bello, J.; Vallet, P.; Perot, T.; Balandier, P.; Seigner, V.; Perret, S.; Couteau, C.; Korboulewsky, N. 2019. How do mixing tree species and stand density affect seasonal radial growth during drought events? Forest Ecology and Management, 432: 436-445.

Blanco-Flórez, J, Silva, J.R.M.; Braga, P.P.C.; Lima, J.T.; Trugilho, P.F. 2015. Simulation in service of young teak wood floors. Revista Matéria, 20: 1048-1060.

Budakçi, M.; Pelit, H.; Sönmez, A.; Korkmaz, M. 2016. The effects of densification and heat post-treatment on hardness and morphological properties of wood materials. BioResources, 11: 7822-7838.

Chery, J.G.; Pace, M.R.; Acevedo-Rodríguez, P.; Specht, C.D.; Rothfels, C.J. 2020. Modifications during Early Plant Development Promote the Evolution of Nature's Most Complex Woods. Current Biology, 30: 237-244.

Cordeiro, I.M.C.C.; Barros, P.L.C.D.; Lameira, O.A.; Gazel Filho, A.B. 2015. Avaliaçấo de plantios de paricá (Schizolobium parahyba var. amazonicum (Huber ex Ducke) Barneby de diferentes idades e sistemas de cultivo no município de Aurora do Pará-PA (Brasil). Ciência Florestal, 25: 679-687.

Cordeiro, I.M.C.C.; Schwartz, G.; Barros, P.L.C. 2019. Timber species performance in secondary forests with over used soils in Eastern Amazonia. Nativa, 7: 800-806.

Cortner, O.; Garrett, R.D.; Valentim, J.F.; Ferreira, J.; Niles, M.T.; Reis, J.; Gil, J. 2019. Perceptions of integrated crop-livestock systems for sustainable intensification in the Brazilian Amazon. Land Use Policy, 82: 841-853.

Dawoe, E.K.; Barnes, V.R.; Oppong, S.K. 2018. Spatio-temporal dynamics of gross rainfall partitioning and nutrient fluxes in shaded-cocoa (Theobroma cocoa) systems in a tropical semideciduous forest. Agroforestry Systems, 92: 397-413.

Del Menezzi, C.H.S.; Silveira, R.R.; Souza, M.R.D. 2010. Predicting flexural properties of six Amazonian hardwoods using stress wave nondestructive method. Acta Amazonica, 40: 325-332.

Dias, F.M.; Almeida, T.H.; Araújo, V.A.; Panzera, T.H.; Christoforo, A.L.; Lahr, F.A.R. 2019. Influence of the apparent density on the shrinkage of 43 tropical wood species. Acta Scientiarum. Technology, 41: e30947.

Evans, J.W.; Senft, J.F.; Green, D.W. 2000. Juvenile wood effect in red alder: analysis of physical and mechanical data to delineate juvenile and mature wood zones. Forest Products Journal, 50: 75-87.

Figueiredo, R.O.; Cak, A.; Markewitz, D. 2020. Agricultural impacts on hydrobiogeochemical cycling in the Amazon: Is there any solution? Water, 12: 763. doi:10.3390/w12030763

Fleming, A.; O'Grady, A.P.; Mendham, D.; England, J.; Mitchell, P.; Moroni, M.; Lyons, A. 2019. Understanding the values behind farmer perceptions of trees on farms to increase adoption of agroforestry in Australia. Agronomy for Sustainable Development, 39: 1-11. doi:10.1007/s13593-019-0555-5
Gérard, J.; Cerre, J.C.; Guibal, D.; Paradis, S. 2017. Tropical Timber Atlas: Technological Characteristics and Uses. Quae, Versailles, 1000p.

Gérard, J.; Paradis, S.; Thibaut, B. 2019. Survey on the chemical composition of several tropical wood species. Bois et Forêts des Tropiques, 342: 79-91.

Gomes, J.M.; Carvalho, J.O.P.D.; Silva, M.G.D.; Nobre, D.N.V.; Taffarel, M.; Ferreira, J.E.R.; Santos, R.N.J. 2010. Survival of seedlings planted in gaps after harvesting in a terra firme rain forest in Paragominas region in the Brazilian Amazonia. Acta Amazonica, 40: 171-178.

Groover, A. 2016. Gravitropisms and reaction woods of forest trees - evolution, functions and mechanisms. New Phytologist, 211: 790-802.

Hein, R.G.; Brancheriau, L. 2018. Comparison between three point and four-point flexural tests to determine wood strength of Eucalyptus specimens. Maderas. Ciencia y Tecnología, 20: 333-342.

Helińska-Raczkowska, L.; Moliński, W. 2003. The effect of the Janka ball indentation depth on the hardness number determined for selected wood species. Folia Forestalia Polonica. 34: 27-36.

Huber, J.A.; Matiu, M.; Hülsbergen, K.J. 2018. First-rotation growth and stand structure dynamics of tree species in organic and conventional short-rotation agroforestry systems. Heliyon, 4: e00645.

Jankowska, A.; Drozdzek, M.; Sarnowski, P.; Horodenski, J. 2017. Effect of extractives on the equilibrium moisture content and shrinkage of selected tropical wood species. BioResources, 12: 597-607.

Kay, S.; Graves, A.; Palma, J.H.; Moreno, G.; Roces-Díaz, J.V.; Aviron, S.; et al. 2019. Agroforestry is paying off-Economic evaluation of ecosystem services in European landscapes with and without agroforestry systems. Ecosystem Services, 36: 100896.

Kenzo, T.; Himmapan, W.; Yoneda, R.; Tedsorn, N.; Vacharangkura, T.; Hitsuma, G.; Noda, I. 2020. General estimation models for aboveand below-ground biomass of teak (Tectona grandis) plantations in Thailand. Forest Ecology and Management, 457: 117701.

Kerkhoff, W.; Alberink, J.; Mattijssen, E.J.A.T. 2015. An empirical study on the relation between the critical angle for bullet ricochet and the properties of wood. Journal of Forensic Sciences, 60: 605-610.

Kloiber, M.; Drdácky, M.; Machado, J.S.; Piazza, M.; Yamaguchi, N. 2015. Prediction of mechanical properties by means of semi-destructive methods: A review. Construction and Building Materials, 101: 1215-1234.

Kuehne, C.; Russel, M.B.; Weiskittel, A.R.; Kershaw Junior, J.A. 2020. Comparing strategies for representing individual-tree secondary growth in mixed-species stands in the Acadian Forest region. Forest Ecology and Management, 459: 117823.

Lima, N.N.; Mendes, L.M.; Sá, V.A.; Bufalino, L. 2013. Mechanical and physical properties of LVL panels made from three amazonic species. Cerne, 19: 407-413.

Mania, P.; Wróblewski, M.; Wójciak, A.; Roszyk, E.; Moliński, W. 2020. Hardness of Densified wood in relation to changed chemical composition. Forests, 11: 506. doi.org/10.3390/f11050506

Mascarenhas, A.R.P.; Sccoti, M.S.V, Melo, R.R.; Corrêa, F.L.O.; Souza, E.F.M.; Andrade, R.A.; Bergamin, A.C.; Müller, M.W. 2017. Physical attributes and soil carbon stocks under different land use in Rondônia State, South Western Amazon. Pesquisa Florestal Brasileira, 37: 19-27. 
Matias, E.F.F.; Alves, E.F.; Silva, M.K.N.; Carvalho, V.R.A.; Coutinho, H.D.M.; Costa, J.G.M. 2015. The genus Cordia: botanists, ethno, chemical and pharmacological aspects. Revista Brasileira de Farmacognosia, 25: 542-552.

Moore, J.R.; Cown, D.J. 2017. Corewood (Juvenile Wood) and its impact on wood utilization. Current Forestry Reports, 3: 107-118.

Moulin, J.C.; Rodrigues, B.P.; Oliveira, J.T.S.; Rosa, R.A.; Oliveira, J.G.L. 2016. Wood characterization of black laurel wood. Pesquisa Florestal Brasileira, 36: 415-421.

Navi, P.; Heger, F. 2011. Combined densification and thermo-hydromechanical processing of wood. MRS Bulletin, 29: 332-336.

Pachas, A.N.A.; Sakanphet, S.; Soukkhy, O.; Lao, M.; Savathvong, S.; Newby, J.C.; Souliyasack, B.; Keoboualapha, B.; Dieters, M.J. 2019. Initial spacing of teak (Tectona grandis) in northern Lao PDR: Impacts on the growth of teak and companion crops. Forest Ecology and Management, 435: 77-88.

Pamerleau-Couture, E.; Rossi, S.; Pothier, D.; Krause, C. 2019. Wood properties of black spruce (Picea mariana (Mill.) BSP) in relation to ring width and tree height in even- and uneven-aged boreal stands. Annals of Forest Science, 76: 43. doi:10.1007/s13595-019-0828-9

Pereira, A.F. 2013. Madeiras Brasileiras: Guia de Combinaçâo e Substituição. Editora Blucher, São Paulo, 132p.

Pereira, E.J.A.L.; Ferreira, P.J.S.; Ribeiro, L.C.S.; Carvalho, T.S.; Pereira, H.B.B. 2019. Policy in Brazil (2016-2019) threaten conservation of the Amazon rainforest. Environmental Science \& Policy, 100: 8-12.

Qiu, H.; Liu, R.; Long, L. 2019. Analysis of chemical composition of extractives by acetone and the chromatic aberration of teak (Tectona Grandis L.F.) from China. Molecules, 24: 1989. doi:10.3390/molecules24101989

Ramage, M.H.; Burridge, H.; Busse-Wicher, M.; Fereday, G.; Reynolds, T.; Wu, G.; et al. 2017. The wood from the trees: The use of timber in construction. Renewable and Sustainable Energy Reviews, 68: 333-359.

Reis, J.C.; Rodrigues, G.S.; Barros, I.; Rodrigues, R.D.A.R.; Garrett, R.D.; Valentim, J.F.; et al. 2020. Integrated crop-livestock system: A sustainable land-use alternative for food production in the Brazilian Cerrado and Amazon. Journal of Cleaner Production, 283: 124580.

Reis, P.C.M.R.; Reis, L.P.; Souza, A.L.; Carvalho, A.M.M.L.; Mazzei, L.; Reis, A.R.S.; Torres, C.M.M.E. 2019. Clustering of Amazon wood species based on physical and mechanical properties. Ciência Florestal, 29: 336-346.

Reydon, B.P.; Fernandes, V.B.; Telles, T.S. 2020. Land governance as a precondition for decreasing deforestation in the Brazilian Amazon. Land Use Policy, 94: 104313.

Rezende, G.M.; Vieira, D.L.M. 2019. Forest restoration in southern Amazonia: Soil preparation triggers natural regeneration. Forest Ecology and Management, 433: 93-104.

Rizanti, D.E.; Darmawan, W.; George, B.; Merlin, A.; Dumarcay, S.; Chapuis, H.; et al. 2018. Comparison of teak wood properties according to forest management: short versus long rotation. Annals of Forest Science, 75: 39. doi: 10.1007/s13595-018-0716-8
Rizvi, R.H.; Newaj, R.; Chatuverdi, O.P.; Prasad, R.; Handa, A.K.; Alam, B. 2019. Carbon sequestration and $\mathrm{CO}_{2}$ absorption by agroforestry systems: An assessment for Central Plateau and Hill region of India. Journal of Earth System Science, 128: 56. doi: 10.1007/s12040-019-1071-3

Santos, H.G.; Jacomine, P.K.T.; Anjos, L.H.C.; Oliveira, V.A.; Lumbreras, J.F.; Coelho, M.R.; Almeida, J.A.; Araujo Filho, J.C.; Oliveira, J.B.; Cunha, T.J.F. 2018. Sistema Brasileiro de Classificação de Solos. Embrapa, Brasília, 353p.

Santos, M.A.; Drescher, R.; Mora, R.; Vendrusculo, D.G.S. 2017. Funçôes de Kozak et al. para afilamento de Cordia goeldiana Huber em plantio homogêneo no município de Vilhena - RO. In: Pasa, M.C.; David, M. (Ed.). Múltiplos Olhares Sobre a Biodiversidade. Carlini \& Caniato Editorial, Cuiabá, p.306-321.

Sargent, R. 2019. Evaluating dimensional stability in solid wood: a review of current practice. Journal of Wood Science, 65: 36. doi. org/10.1186/s10086-019-1817-1

Scatolino, M.V.; Bufalino, L.; Mendes, L.M.; Guimarães Júnior, M.; Tonoli, G.H.D. 2017. Impact of nanofibrillation degree of eucalyptus and Amazonian hardwood sawdust on physical properties of cellulose nanofibril films. Wood Science and Technology, 51: 1095-1115.

Soares-Filho, B.S.; Oliveira, A.S.; Rajão, R.G.; Oliveira, U.; Santos, L.R.S.; Assunção, A.C.; et al. 2017. Economic Valuation of Changes in the Amazon Forest Area: Economic Losses by Fires to Sustainable Timber Production. Centro de Sensoriamento Remoto/UFMG, Belo Horizonte, 46p.

Stabile, M.C.; Guimarães, A.L.; Silva, D.S.; Ribeiro, V.; Macedo, M.N.; Coe, M.T.; Pinto, E.; Moutinho, P.; Alencar, A. 2020. Solving Brazil's land use puzzle: Increasing production and slowing Amazon deforestation. Land Use Policy, 91: 104362.

Tenorio, C.; Moya, R. 2019. Evaluation of wood properties of four ages of Cedrela odorata trees growing in agroforestry systems with Theobroma cacao in Costa Rica. Agroforestry Systems, 93: 973-988.

Virgulino, A.P.; Santos, J.S.; Corrêa, F.L.O.; Müller, M.W. 2015. Analysis of the productive value of forest species in an agroforestry system, Rondônia, Brazil. Agrotrópica, 27: 167-172.

Yoshihara, H.; Furushima, T. 2003. Shear strengths of wood measured by various short beam shear test methods. Wood Science and Technology, 37: 189-197.

Yoshihara, H.; Ohta, M. 2000. Estimation of the shear strength of wood by uniaxial-tension tests of off-axis specimens. Journal of Wood Science, 46: 159-163.

Zalloni, E.; Battipaglia, G.; Cherubini, P.; Saurer, M.; Micco, V. 2019. Wood growth in pure and mixed Quercus ilex L. forests: drought influence depends on site conditions. Frontiers in Plant Science, 10: 397. doi: 10.3389/fpls.2019.00397

RECEIVED: 08/07/2020
ACCEPTED: 23/03/2021
ASSOCIATE EDITOR: João Paulo Silva

